\title{
Improved Rooting of Peach Rootstock GF677 Hardwood Stem Cuttings Through Cultural Practices
}

\author{
C. Tsipouridis and T. Thomidis ${ }^{1}$ \\ Pomology Institute, Naoussa, P.C. 59200, Naoussa, Greece \\ Additional index words. cutting length, planting depth, irrigation, soil compression, \\ blanching, hardwood cuttings
}

\begin{abstract}
The effect of cutting length, planting depth, irrigation of cuttings, soil compaction following frost, and prior blanching on rooting of ' GF677' hardwood stem cuttings stuck directly into a nursery row was studied. The results showed that cuttings cut to 30 cm lengths rooted best of all length treatments tested. Cuttings planted so that the shoot tips were level with the soil surface $(0-\mathrm{cm}$-deep treatment) rooted with significantly higher percentages than did the other planting depths. Irrigation, applied immediately after planting cuttings into a nursery row, had a negative effect on rooting. Cuttings that were loosened from the soil as a result of frost heaving rooted better when pushed back into the soil than did the controls. Finally, cuttings made from shoots that were treated by wrapping the base in red or black tape rooted better than the unwrapped controls.
\end{abstract}

The clonally propagated peach rootstock 'GF677' (almond $x$ peach) is useful in the control of replant diseases of peach, particularly in trees growing on moderate or poor fertility soils (Stylianides et al., 1988). Vegetative propagation of this rootstock has proven to be difficult and much research has been attempted to improve rooting, but with little advantages (Stylianides et al., 1988). The purpose of this study was to investigate the effect of cutting length, planting depth, irrigation of cuttings, soil compaction following frost, and prior blanching on rooting of 'GF677' hardwood stem cuttings stuck directly into a nursery row.

\section{Materials and Methods}

Cuttings of 'GF677'were takenfromhealthy, vigorous 7-year-old trees growing on the experimental farm of the Pomology Inst., Naoussa, Greece. In Nov. 1996 and 1997, dormant cuttings ( 0.8 to $1 \mathrm{~cm}$ diameter) were taken from the middle section of shoots from current-season growth. The basal end of the cuttings were dipped in a $50 \%$ ethanol : water mixture containing $1 \mathrm{~g} \cdot \mathrm{L}^{-1} \mathrm{IBA}$, dried for 30 min under room conditions, coated with $75 \%$ Captan powder, and the cuttings were planted into a nursery row. The nursery row was a raised bed $(20 \mathrm{~cm}$ high) of a clay or clay-loam soil depending upon soil depth. The initial $\mathrm{pH}$ was 7.2 at 0 to $30 \mathrm{~cm}, 7.5$ at 30 to $60 \mathrm{~cm}$, and 7.8 at 60 to $90 \mathrm{~cm}$. Organic matter was $1.7 \%$ and water permeability good, as a result of a sandy rocky subsoil. During the dry spring weather, the cuttings were sprinkler irrigated

Received for publication 4 Sept. 2003. Accepted for publication 20 Jan. 2004.

${ }^{1}$ To whom reprint requests should be addressed. Phone: +30332041548, Fax: +302332041178, E-mail: thomi-1@otenet.gr
(120 mm per h, $40 \mathrm{~mm}$ total) every $15 \mathrm{~d}$ and were sprayed (1.5\% Captan 83WP,Zeneca and $0.4 \%$ Talstar, FMC Hellas) to protect against insects and disease. Nonrooted cuttings were checked for infection by pathogens, by placing pieces from the base of cuttings on cornmeal agar, hemp seed agar, potato dextrose agar, and Lutz medium.

A study was initiated that included treatments consisting of five cutting lengths (10, $15,20,25$, or $30 \mathrm{~cm}$ ) and five planting depths (cutting tips $6,4,2$, or $0 \mathrm{~cm}$ above the soil surface or $1 \mathrm{~cm}$ below the soil surface), arranged in a completely randomized design with five replications of 10 cuttings per replication. The study was terminated and percent rooting was determined on 25 May the following year (May 1997 and 1998). All data were angular transformed before statistical analysis.

A second study was initiated to determine the influence of irrigation on rooting of ' GF677' hardwood cuttings. This study consisted of wet and dry treatments applied to a soil at $48 \%$ of its water-holding capacity. The dry treatment was not irrigated at all during the experiment, while the wet treatment received irrigation immediately following planting $\left(2 \mathrm{~m}^{3}\right.$ of water per $50 \mathrm{~m}^{2}$ of soil surface). The cuttings in both treatments were treated with IBA as described above and planted in a nursery row on 2 Nov. 1995 and 1996. Treatments were arranged in a completely randomized design with eight replications of 100 cuttings per replication. The number of rooted cuttings was recorded on 25 May the following year.

To determine the effect of soil compaction on rooting of cuttings, a study was initiated with treatments that consisted of a control, smooth firming of the soil by hand around the cutting after pushing the cutting into the soil to the desired depth, or compacting the soil around the cutting with pressure from the foot after it had been hand inserted to the desired depth into the nursery row. These studies were initiated following a frost that occurred in December of $1996\left(-10^{\circ} \mathrm{C}\right)$ and $1997\left(-8.2{ }^{\circ} \mathrm{C}\right)$ using $30-\mathrm{cm}$ cuttings, planted at the $0-\mathrm{cm}$ depth, and treated with $2 \mathrm{~g} \cdot \mathrm{L}^{-1}$ IBA on 2 Nov. of each year. The treatments were arranged in a completely randomized design with five replications of 100 cuttings per replication. Data were recorded on 19 May the year following treatment initiation.

A fourth study was initiated to investigate the effect of various colors of tape on the rooting of 'GF677' hardwood cuttings. On 26 Sept. 1996 and $1997 \approx 2$-cm-wide sections of the base of shoots from current-year's growth were wrapped (without overlapping) with 2cm-wide polyethylene tape (0.05 $\mathrm{mm}$ thick) painted with Glassolack colors no. 19 (red), 531 (black), or 680 (blue), and securing the tape with adhesive tape. After $40 \mathrm{~d}$, the tapes were removed, cuttings made, and the previously taped areas of the cuttings were treated with $1 \mathrm{~g} \cdot \mathrm{L}^{-1}$ IBA. The experimental design was a completely randomized design with two replications of 10 cuttings per replication. Percent rooting data were collected on 9 May of the following year.

\section{Results and Discussion}

Cutting length played a significant role in the rooting of 'GF677' hardwood cuttings. Cuttings cut to $30-\mathrm{cm}$ lengths rooted best of all length treatments tested (Table 1). These results agree with those reported by Tort et al. (1995). Bhattacharjee and Thimmappa (1991) reported a significant interaction between IBA concentration and cutting length of Pogostemon patchouli (Labiatae). The greatest rooting percentage was found when cuttings were 15 $\mathrm{cm}$ in length and treated with $2 \mathrm{~g} \cdot \mathrm{L}^{-1}$ IBA. Cuttings planted so that the shoot tips were level with the soil surface $(0$-cm-deep treatment) rooted with significantly higher percentages than did the other planting depths (Table 1). This was probably a result of protection of the cuttings from unfavorable climatic conditions, resulting in a reduction in cutting dehydration (unpublished, Tsipouridis). However, Paizkill and Feldman (1993) found that depth of planting of Simmondsia chinensis (Buxaceae) stem cuttings had no effect on rooting percentage. Hocevar et al. (1998) reported that basal cuttings of Prunus pumila L. (Rosaceae) rooted best $(94.8 \%)$, followed by cuttings taken from the median shoot section, with terminal cuttings rooting the poorest $(49.1 \%)$. The root system produced by the $P$. pumila $\mathrm{L}$. cuttings had a well-developed root system that extended to $37 \mathrm{~mm}$.

Irrigation, applied immediately after planting cuttings into a nursery row, had a negative effect on rooting (dry control, $41.9 \%$, irrigated, $36.9 \%$ with $\mathrm{LSD}_{0.05}=3.2$ performed on angular transformed data). The reduced rooting percentage recorded for the irrigated treatment was a possible result of increased heat conductivity of the wet soil, resulting in a lowering of the soil temperature at the cutting base below the levels necessary for root formation. Reduced aeration (low $\mathrm{O}_{2}$, high $\mathrm{CO}_{2}$, or high ethylene) at the cutting base in the irrigated treatments could have resulted in a lower rooting percentage as well. 
Table 1. Effect of cutting length and planting depth on percent rooting of 'GF677' hardwood shoot cuttings (\% original values) ${ }^{z, y}$

\begin{tabular}{lllclc}
\hline Part above soil & \multicolumn{5}{c}{ Length of cuttings $(\mathrm{cm})$} \\
\cline { 2 - 6 } surface $(\mathrm{cm})$ & 10 & 15 & 20 & 25 & 30 \\
\hline 6 & $0 \mathrm{~h}$ & $0 \mathrm{~h}$ & $2 \mathrm{~h}$ & $6 \mathrm{gh}$ & $32 \mathrm{de}$ \\
4 & $0 \mathrm{~h}$ & $0 \mathrm{~h}$ & $6 \mathrm{gh}$ & $22 \mathrm{ef}$ & $44 \mathrm{~cd}$ \\
2 & $2 \mathrm{~h}$ & $4 \mathrm{~h}$ & $22 \mathrm{ef}$ & $40 \mathrm{~d}$ & $62 \mathrm{ab}$ \\
0 & $4 \mathrm{~h}$ & $8 \mathrm{fgh}$ & $40 \mathrm{~d}$ & $64 \mathrm{ab}$ & $76 \mathrm{a}$ \\
-1 & 0 & $0 \mathrm{~h}$ & $8 \mathrm{fgh}$ & $20 \mathrm{efg}$ & $56 \mathrm{bc}$ \\
\hline
\end{tabular}

${ }^{2} 0.25$ was used instead of 0 for statistical analysis.

${ }^{y}$ Values are the means of two experiments, each with 50 cuttings. Results were similar according to the Bartlett's test of homogeneity of variance, so data were combined. LSD ${ }_{005}$ for interaction (angular transformation) $=15.39$

Howard and Harrison-Murray (1998) reported that the highest rooting frequency of M.26 apple cuttings was associated with no change in or a small decrease in rooting media water content during the first $9 \mathrm{~d}$ of propagation.

Cuttings that were loosened from the soil as a result of frost heaving rooted better when pushed back into the soil than did the controls (50\% rooting vs. $40 \%$ rooting for controls; $\mathrm{LSD}_{0.05}=8.93$ ). Compaction of the soil around the cutting had no effect on percent rooting. Compaction could have resulted in poor aeration as a result of soil capping, and the base of control cuttings could have dried out as a result of soil loosening brought about by the frost heaving.
Cuttings made from shoots that were treated by wrapping the base in red or black tape rooted better $(65 \%)$ than the unwrapped controls $(50 \%)\left(\mathrm{LSD}_{005}=8.12\right)$. These data support results with apples that show a rooting enhancement effect with etiolation (HarrisonMurray, 1981a, 1981b; Howard, 1978).

No pathogens were isolated from the nonrooted cuttings.

\section{Literature Cited}

Bhattacharjee, S.K. and D.K. Thimmappa. 1991. Studies on the growth hormone, length of cuttings and number of leaves on root formation of Pogostemon patchouli Benth. Indian Perf. 35:71-76
Harrison-Murray, R.S. 1981a. Etiolation of stock plants for improved rooting of cuttings, I. Opportunities suggested by work with apple. Proc. Intl. Plant Prop. Soc. 31:386-391b.

Harrison-Murray, R.S. 1981b. Improvement of rooting by etiolation pre-treatment. Com. For. Inst. Occas. Papers 15:12-13

Hocevar, I., F. Stampar, and M. Hudina. 1998. Propagation of Prunus pumila L. rootstock with wood cuttings with use of IBA. Zbornik Biotehniske fakultete Univerze v Ljubljani (Slovenia). Kmetijstvo. 71:53-56.

Howard, B.H. 1978. Plant propagation report. East Malling Res. Sta. for 1977. p. 67-73

Howard, B.H. and R.S. Harrison-Murray. 1988. Effects of water status on rooting and establishment of leafless winter (hardwood) cuttings. Acta Hort. 227:134-140

Palzkill, D.A. and W.R. Feldman. 1993. Optimizing rooting of jojoba stem cuttings: effects of basal wounding, rooting medium and depth of insertion in medium. J. Amer. Oil Chem. Soc. 70:1221-1224.

Stylianides, D.C., G.D. Syrgianidis, and D.D. Almaliotis. 1988. The peach rootstocks: A review of bibliography with relative observations in Greece. Agric. Tech. 12:34-69

Tort, J.D., G. Jacobs, and K.I. Theron. 1995. Vegetative propagation of hardwood cuttings of peach X almond hybrid "GF677". II. Effect of cutting dimensions and field planting versus pre-plant storage. J. Southern Afric. Soc. Hort. Sci. 5:69-71. 